\title{
Relationship of parental age with set shifting and reversal learning in schizophrenia
}

\author{
Dimitrios Kontis ${ }^{1 *}$, Spiros Kleisas ${ }^{1}$, Eirini Theochari ${ }^{1}$, Stamatina Kalogerakou², Angeliki Andreopoulou', Rafail Psaras ${ }^{1}$, \\ Charalambos Karouzos ${ }^{1}$, Eleftheria Tsaltas ${ }^{2}$ \\ From $1^{\text {st }}$ International Congress on Neurobiology and Clinical Psychopharmacology and European \\ Psychiatric Association Conference on Treatment Guidance \\ Thessaloniki, Greece. 19-22 November 2009
}

\section{Background}

Advanced parental age at birth has been associated with the risk of schizophrenia and has been linked to cognitive deficits in children. However, the relationship of parental age with cognition and with attentional flexibility in schizophrenia remains unknown.

\section{Materials and methods}

27 patients with schizophrenia, were tested on the intradimensional/extra-dimensional set-shifting task (IEDS) of the Cambridge Neuropsychological Test Automated Battery (CANTAB) in an acute psychiatric ward. The paternal $(\mathrm{PAB})$ and maternal age at birth (MAB) were also registered. Statistical correlation analyses and the Mann-Whitney test were performed using the SPSS.

\section{Results}

$\mathrm{PAB}$ positively correlated with the intra-dimensional shifting errors in the IEDS (rho $=0.7, \mathrm{p}=0.005$ ). $\mathrm{MAB}$ positively correlated with both intra- and extra-dimensional reversal errors (rho $=0.572, \mathrm{p}=0.026$ and rho $=$ $0.9, \mathrm{p}=0.037$, respectively). When we divided our subjects into two groups according to their PAB ( $\geq$ and $<$ 30 years), no differences were found in any cognitive measure. However, the group with a $M A B \geq 30$ years, showed increased intra-dimensional reversal errors compared with the group with a MAB $<30$ years $(\mathrm{p}=0.03$ and 0.029 respectively).

\section{Conclusions}

Increasing parental $\mathrm{PAB}$ showed an inverse relationship with the intra-dimensional shifting ability, but did not affect rule reversal performance. MAB was associated

\footnotetext{
${ }^{1}$ 1st Psychiatric Department, Psychiatric Hospital of Attica, Athens, Greece
}

with errors in both intra- and extra-dimensional reversal in schizophrenia.

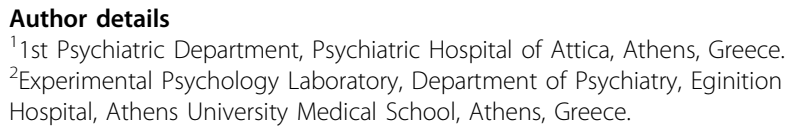

Published: 22 April 2010

\section{References}

1. Malaspina D, Harlap S, Fennig S, Heiman D, Nahon D, Feldman D, Susser ES: Advancing paternal age and the risk of schizophrenia. Arch Gen Psychiatry 2001, 58(4):361-7.

2. Saha S, Barnett AG, Foldi C, Burne TH, Eyles DW, Buka SL, McGrath JJ: Advanced paternal age is associated with impaired neurocognitive outcomes during infancy and childhood. PLoS Med 2009, 10,6(3):e40.

doi:10.1186/1744-859X-9-S1-S125

Cite this article as: Kontis et al:: Relationship of parental age with set shifting and reversal learning in schizophrenia. Annals of General Psychiatry 2010 9(Suppl 1):S125.
Submit your next manuscript to BioMed Central and take full advantage of:

- Convenient online submission

- Thorough peer review

- No space constraints or color figure charges

- Immediate publication on acceptance

- Inclusion in PubMed, CAS, Scopus and Google Scholar

- Research which is freely available for redistribution

Submit your manuscript at www.biomedcentral.com/submit
() Biomed Central 